\title{
Comparative study of pain killer drugs effects after the dental implant placement in the active adult population
}

\author{
Studiu comparativ privind efectele administrării medicaţiei antialgice \\ postimplantar la populaţia adultă activă
}

\section{Ruxandra Nicolette Voinea Georgescu' ${ }^{1}$, Cristian Niky Cumpătă ${ }^{1}$, Mihaela Răescu ${ }^{1}$, Mircea Gheorghiță ${ }^{2}$ Andreea Gabriela Nicola², Dana Cosac ${ }^{1}$ \\ ${ }^{1}$ Facultatea de Medicină Dentară, Universitatea „Titu Maiorescu“, Bucureşti, România \\ ${ }^{2}$ Facultatea de Medicină Dentară, Universitatea de Medicină şi Farmacie din Craiova, România}

\begin{abstract}
There is controversy in recent studies on the use of NSAIDs used to control pain and swelling after the insertion of dental implants that may interfere with the osteointegration process. The purpose of this study is to compare the effect of tramadol versus codeine in pain management after the insertion of dental implants. In conclusion, according to this study, tramadol - containing analgesics are significantly more effective than those containing codeine / caffeine in reducing postoperative pain. It was also found that the selected group of analgesics con-taining codeine / caffeine were significantly more effective than those containing tramadol in reducing swelling, which was reported to be significantly lower in the first 3 days in the codeine / caffeine group. As a result, codeine / caffeine-containing analgesics are effective and acceptable in reducing pain and inflammation.
\end{abstract}

Keywords: tramadol hydrocloride, codeine phosphate hydrate, pain management

\section{REZUMAT}

Există controverse în studiile recente privind utilizarea AINS utilizate pentru controlul durerii şi tumefacţiei după inserarea implanturilor dentare, care pot interfera cu procesul de osteointegrare. Scopul acestui studiu a fost de a compara efectul substanţelor pe bază de clorhidrat de tramadol în comparaţie cu substanţele pe bază de fosfat de codeină + cafeină, în controlul durerii după manopere de inserarea ale implanturilor dentare. În concluzie, conform acestui studiu, analgezicele cu conţinut de tramadol sunt semnificativ mai eficiente decât cele care conţin codeină/cofeină în reducerea durerii postoperatorii. S-a constatat, de asemenea, că lotul de analgezice care conţine codeină/cofeină sunt semnificativ mai eficiente decât cele care conţin tramadol în reducerea tumefacţiei, care a fost raportată a fi semnificativ mai mică în primele 3 zile la lotul codeină/ cofeină. Ca rezultat, analgezicele cu conţinut de codeină/cofeină sunt eficiente şi acceptabile în reducerea durerii şi inflamaţiei.

Cuvinte cheie: clorhidrat de tramadol, fosfat de codeină, managementul durerii

\section{INTRODUCERE}

Inserarea implanturilor dentare a devenit o intervenţie chirurgicală de rutină. Este însoţită de obicei de dureri şi tumefacţii uşoare până la moderate, rar depăşind limitele normale. Există diferite studii cu privire la severitatea durerii şi tumefacţiei, în funcţie de tipul intervenţiei, medicaţie, pragul durerii, sistemul imunitar al pacientului, experienţa medi- cului $(23,13)$. Medicamente antiinflamatoare nesteroidiene (AINS), cum ar fi ibuprofenul, diclofenacul şi naproxenul, etoricoxibum, celecoxibum, sunt eficiente în reducerea mediatorilor inflamaţiei care cauzează durere uşoară până la moderată şi inflamaţie postoperatorie.

Rezultate contradictorii au fost raportate în studiile recente privind indicaţiile AINS pentru con- 
trolul durerii după inserarea implanturilor dentare, şi anume afectarea osteointegrării implanturilor după consumul pe termen lung de AINS (peste o săptămână) $(1,6,12,14,24)$.

Acetaminofenul (paracetamolul) este utilizat pentru ameliorarea durerii şi a febrei; este de obicei combinat cu alte medicamente şi este utilizat pentru tratamentul durerii uşoare până la moderată. Se crede că acetaminofenul influenţează sistemul nervos central; unii cercetători au remarcat că scade pragul durerii prin inhibarea activităţii ciclooxigenazei-3. Acetaminofenul nu inhibă enzima COX-1 în ţesuturi; prin urmare, nu are efecte secundare gastro-intestinale. Combinaţia de acetaminofen $\mathrm{cu}$ agenţi antiinflamatori nesteroidieni poate fi eficientă în tratamentul durerii acute şi cronice $(16,25)$.

Combinarea analgezicelor poate creşte eficacitatea, dar fără scăderea dozei, ceea ce ar putea duce la riscuri ulterioare; prin urmare, substanţele pe bază de cofeină, codeină sau tramadol ar putea fi combinate cu acetaminofen pentru a-şi creşte eficacitatea (7).

Cafeina joacă un rol important în controlul durerii, structura cofeinei fiind similară cu structura adenozinei, care este un inhibitor al activităţii neuronale în sistemul nervos central sistem (CNS) şi sistemul nervos periferic (PNS), având diverse efecte modulare prin receptorii săi - s-a demonstrat că activarea receptorilor A1 şi A2A conduce la antinocicepţia în durerea neuropată, nociceptivă, şi modele inflamatorii (26). Structura cofeinei este similară cu adenozina şi, prin urmare, concurează cu adenozina pentru receptorii $\mathrm{A} 2 \mathrm{~A}$, determinând inhibarea acestora. În ciuda acestui fapt, cofeina nu modifică eliberarea dopaminei şi, prin urmare, nu are potenţial asemenea cocainei. Înţelegerea acestor efecte duce la interesul reînnoit în ceea ce priveşte cafeina ca o opţiune nouă pentru controlul durerii (4). Cafeina îşi exprimă efectul său direct prin blocarea centrală a receptorilor de adenozină, care influenţează semnalizarea durerii sau prin blocarea receptorilor periferici de adenozină $(3,4,17)$,

Există şi alte studii care dovedesc rolul cafeinei în diminuarea durerii prin influenţarea receptorilor de adenozină în receptorii sistemului nervos central. Rezultate promiţătoare au fost obţinute de cercetătorii prin terapia combinată cofeină-acetaminofen pentru controlul durerii postoperatorii. Cofeina are efecte vasoconstrictoare asupra creierului şi sistemului vascular periferic, reducând durerile de cap şi migrenele $(2,10)$.

Având în vedere rezultatele conflictuale raportate în legătură cu eliminarea efectului AINS asupra osteointegrării implantului $(1,6,12,24)$ şi cu privire la importanţa osteointegrării în stabilizarea implanturilor dentare, acest studiu face o comparaţie între 2 combinaţii de substanţe cu efecte analgezice care nu stimulează sângerarea.

Este un studiu clinic triplu-orb care studiază administrarea de analgezice cu conţinut cafeină/codeină/acetaminofen în comparaţie cu analgezice cu conţinut tramadol/acetaminofen, pentru a evalua severitatea durerii şi inflamaţiei postimplantar.

\section{MATERIAL ŞI METODĂ}

Studiul randomizat triplu-orb a inclus 30 de pacienţi adulţi.

Criterii de selecţie şi includere a pacienţilor în studiu:

- edentaţie unidentară mandibulară;

- sănătoşi din punct de vedere sistemic;

- lăţimea şi înălţimea corespunzătoare a osului, fără necesitate de grefare osoasă;

- utilizarea unui singur protocol şi acelaşi sistem de implant.

Criterii de excludere:

- afecţiuni sistemice decompensate sau psihice grave;

- infecţii locale;

- coagulopatii;

- sensibilitatea cunoscută la AINS, tramadol, codeină, cofeină şi acetaminofen;

- sarcină sau lactaţie.

S-au întocmit acordurile informate ale pacienţilor participanţi la acest studiu împreună cu broşurile informativ-explicative. Fiecare pacient a fost informat asupra introducerii în studiu şi a semnat acordul informat, acesta fiind un criteriu de selecţie a introducerii lui în evaluare.

Au fost împărţiţi în 2 loturi de câte 15 pacienţi; au fost aplicate coduri aleatorii în funcţie de numărul de pacienţi şi de analgezice, iar pentru fiecare pacient a fost ales la întâmplare un cod. Apoi, în funcţie de cod, un analgezic a fost livrat de către asistentă. Această procedură a fost executată la întâmplare, prin urmare, nici pacientul, nici medicul 
nu a ştiut ce analgezic primeşte, asistenta a fost singura persoană informată (studiu clinic triplu-orb randomizat). Scopul studiului a fost explicat pacienţilor la început, dar nu li s-a spus cine ce medicament va primi. Pacienţilor li s-a comunicat să nu folosească nici un medicament suplimentar pentru durere sau inflamaţie. Pacienţii din lotul $1(n=15)$ au primit analgezic pe bază de tramadol/acetaminofen $37,5 \mathrm{mg} / 325 \mathrm{mg}$ şi pacienţii din grupul II ( $\mathrm{n}=$ 15) au primit analgezic pe bază de codeină/cafeină/ acetaminofen $8 \mathrm{mg} / 30 \mathrm{mg} / 500 \mathrm{mg}$. Toţi pacienţii au primit cu 1 oră înaintea intervenţiei $2 \mathrm{~g}$ amoxicilină. Durerea preoperatorie a fost evaluată utilizând o scală vizuală analogică (VAS)astfel încât durerea a fost înregistrată de la 0 - fără durere, la 10 - reprezentând durere severă. Pacienţii şi-au marcat nivelul de durere pe coloana de relevanţă (Figura 1).

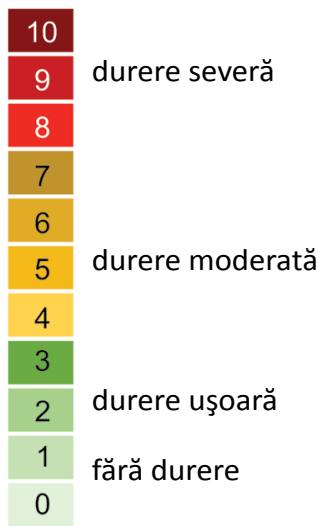

FIGURA 1. Scală reprezentând nivelul de durere resimțit de pacient
Durerea pacienţilor a fost măsurată timp de 1 oră, 4 ore, 8 ore, 12 ore, 1 zi, 2 zile şi 1 săptămână după intervenţie. Pentru a verifica tumefacţia, am folosit criteriile VAS introduse de Pasqualini şi colab., în 2005 (Tabelul 1).

TABELUL 1. Determinarea tumefacției, bazată pe criteriile VAS introduse de Pasqualini şi colab.

\begin{tabular}{|l|l|l|}
\hline VAS 0 & Fără tumefacție & pacientul nu simte tumefacție \\
\hline VAS 1 & $\begin{array}{l}\text { Tumefacție } \\
\text { ușoară }\end{array}$ & $\begin{array}{l}\text { pacientul simte o tumefacție } \\
\text { ușoară, dar nu fără importanță }\end{array}$ \\
\hline VAS 2 & $\begin{array}{l}\text { Tumefacție } \\
\text { moderată }\end{array}$ & $\begin{array}{l}\text { tumefacția semnificativă, fără } \\
\text { tulburări în masticație și deglutiție }\end{array}$ \\
\hline VAS 3 & $\begin{array}{l}\text { Tumefacție } \\
\text { severă }\end{array}$ & $\begin{array}{l}\text { tumefacția este remarcabilă și face } \\
\text { dificilă masticația }\end{array}$ \\
\hline VAS 4 & $\begin{array}{l}\text { Tumefacție } \\
\text { foarte severă }\end{array}$ & $\begin{array}{l}\text { tumefacția severă și evidentă, } \\
\text { masticație dificilă, trismus ușor }\end{array}$ \\
\hline VAS 5 & $\begin{array}{l}\text { Tumefacție } \\
\text { extremă }\end{array}$ & $\begin{array}{l}\text { tumefacția foarte severă cu } \\
\text { dificultate în masticație și trismus } \\
\text { persistent }\end{array}$ \\
\hline
\end{tabular}

\section{REZULTATE}

Compararea durerii şi tumefacţiei în ambele grupuri.

Durerea la 1 oră nu au arătat niciun fel de diferenţe semnificative - între cele două loturi, dar la intervalele 4,8 şi $12 \mathrm{~h}$ severitatea durerii la lotul cu analgezic pe bază de tramadol a fost semnificativ mai mică decât la lotul cu analgezic pe bază de codeină/cafeină (p: 0,001). Este de remarcat că severitatea durerii în această perioadă a fost moderată în ambele grupuri (VAS a fost cuprinsă între 3 şi 7, p $=0,001)$ (Tabelul 2).

TABELUL 2. Nivelul durerii (scor VAS) pentru codeină/cafeină versus tramadol

\begin{tabular}{|l|l|c|c|c|c|c|c|c|}
\hline Parametru & Grup & $\mathrm{n}$ & $\begin{array}{c}\text { scor } \\
\text { VAS }\end{array}$ & SD & Min & Max & Med & $\mathrm{p}$ \\
\hline Durere la 1 oră & codeină/cafeină & 15 & 0,34 & 0,514 & 0 & 2 & 0,00 & 0,592 \\
\hline & tramadol & 15 & 0,47 & 0,546 & 0 & 2 & 0,50 & \\
\hline Durere la 4 ore & codeină/cafeină & 15 & 5,72 & 1,324 & 4 & 9 & 5,50 & 0,001 \\
\hline & tramadol & 15 & 4,03 & 1,461 & 2 & 9 & 4,00 & \\
\hline Durere la 8 ore & codeină/cafeină & 15 & 6,08 & 1,312 & 4 & 10 & 6.00 & 0,001 \\
\hline & tramadol & 15 & 4,28 & 1,598 & 2 & 10 & 4,00 & \\
\hline Durere la 12 ore & codeină/cafeină & 15 & 5,11 & 1,812 & 1 & 10 & 5,00 & 0,001 \\
\hline & tramadol & 15 & 3,34 & 1,114 & 2 & 6 & 3,00 & \\
\hline Durere la 24 ore & codeină/cafeină & 15 & 2,88 & 0,648 & 2 & 4 & 3,00 & 0,071 \\
\hline & tramadol & 15 & 2,41 & 1,011 & 1 & 5 & 2,00 & \\
\hline Durere la 48 ore & codeină/cafeină & 15 & 0,86 & 0,521 & 0 & 2 & 1,00 & 0,188 \\
\hline & tramadol & 15 & 0,82 & 1,076 & 0 & 5 & 1,00 & \\
\hline Durere la 72 ore & codeină/cafeină & 15 & 0,58 & 0,723 & 0 & 2 & 1,00 & 0,074 \\
\hline & tramadol & 15 & 0,19 & 0,598 & 0 & 2 & 0,00 & \\
\hline Durere la 1 săpt & codeină/cafeină & 15 & 0,15 & 0,491 & 0 & 1 & 0,00 & 0,083 \\
\hline & tramadol & 15 & 0,00 & 0,000 & 0 & 0 & 0,00 & \\
\hline
\end{tabular}


Valoarea maximă a severităţii durerii a fost la 8 ore, ajungând la minim după o săptămână. Tumefacţia a fost de asemenea comparată între cele două grupuri şi s-a constatat că tumefacţia postoperator în prima, a doua şi a treia zi în lotul cu substanţă pe bază de codeină/cafeină a fost semnificativ mai scăzută decât cea din lotul cu substanţă pe bază de tramadol $(\mathrm{p}=0,015)$.

Severitatea inflamaţiei în lotul II, în comparaţie cu lotul I, nu a fost semnificativ diferită o săptămână mai târziu. Severitatea inflamaţiei în ambele loturi a prezentat modificări semnificative în timpul studiului $(\mathrm{p}=0,001)$ (Tabelul 3).

Durerea a scăzut semnificativ de la început până la sfârşit în ambele grupuri $(p=0,001)$. O comparaţie detaliată în lotul II - s-a constatat că severitatea durerii la 1 oră şi la 1 săptămână a fost semnificativ mai mică decât la intervalele 4,8 şi 12 h şi în ziua 1. Cu toate acestea, intervalul 1 oră şi 1 săptămână nu au fost semnificativ diferite de intervalul de timp de 2 zile, 3 zile şi 1 săptămână. Durerea a fost semnificativ mai puţin severă în a doua şi a treia zi comparativ cu intervalele 4,8 şi 12 ore.

În lotul I, severitatea durerii la intervalul 1 săptămână şi 3 zile a fost semnificativ mai mică decât la intervalele de 4,8 şi 12 ore. Severitatea durerii la 1 oră şi la 2 zile a fost semnificativ mai mică decât la 4,8 şi 12 ore.

$\mathrm{Nu}$ s-au observat diferenţe semnificative la alte intervale de timp.

Tumefacţia după intervenţia chirurgicală a fost maximă la 1 zi şi apoi, de la a treia zi, inflamaţia a scăzut până la o săptămână după intervenţie. Inflamaţia în lotul de analgezice pe bază de codeină/cofeină a fost semnificativ mai mică decât în lotul cu analgezic pe bază de tramadol în primele 3 zile, însă diferenţa nu a fost semnificativă la o săptămână.

În comparaţiile făcute în cadrul fiecărui grup, severitatea inflamaţiei în lotul II, în a şaptea zi a fost semnificativ mai scăzută decât în prima, a doua şi a treia zi. $\mathrm{Nu}$ au existat diferenţe semnificative între prima, a doua şi a 3-a zi.

\section{DISCUȚII}

În acest studiu triplu-orb, s-a observat că severitatea durerii medii raportată de pacienţii din lotul cu analgezic pe bază de tramadol/acetaminofen a fost semnificativ mai mică decât cea din lotul cu analgezic pe bază de codeină/cafeină până la 12 ore

TABELUL 3. Nivelul tumefacției (scor VAS) pentru codeină/cafeină versus tramadol

\begin{tabular}{|l|l|c|c|c|c|c|c|c|}
\hline Parametru & Lot & $\mathrm{n}$ & Scor VAS & $\mathrm{SD}$ & MIN & Max & Med & $\mathrm{p}$ \\
\hline Tumefacția la 1 zi & codeină/cafeină & 15 & 1,23 & 0.474 & 0 & 3 & 1,00 & 0,018 \\
\hline & tramadol & 15 & 1,42 & 0,853 & 0 & 4 & 1,00 & \\
\hline Tumefacția la 2 zile & codeină/cafeină & 15 & 1,76 & 0,835 & 1 & 4 & 2,00 & 0,007 \\
\hline & tramadol & 15 & 2,76 & 0,675 & 1 & 2 & 2,00 & \\
\hline Tumefacția la 3 zile & codeină/cafeină & 15 & 1,83 & 0,698 & 0 & 3 & 2,00 & 0,001 \\
\hline & tramadol & 15 & 2,63 & 0,602 & 2 & 4 & 3,00 & \\
\hline Tumefacția la 1 săpt & codeină/cafeină & 15 & 0,00 & 0,000 & 0 & 0 & 0,00 & 0,65 \\
\hline & tramadol & 15 & 0,42 & 0,576 & 0 & 1 & 0,00 & \\
\hline
\end{tabular}

Evaluarea durerii codeină/cafeină vs tramadol - scor VAS

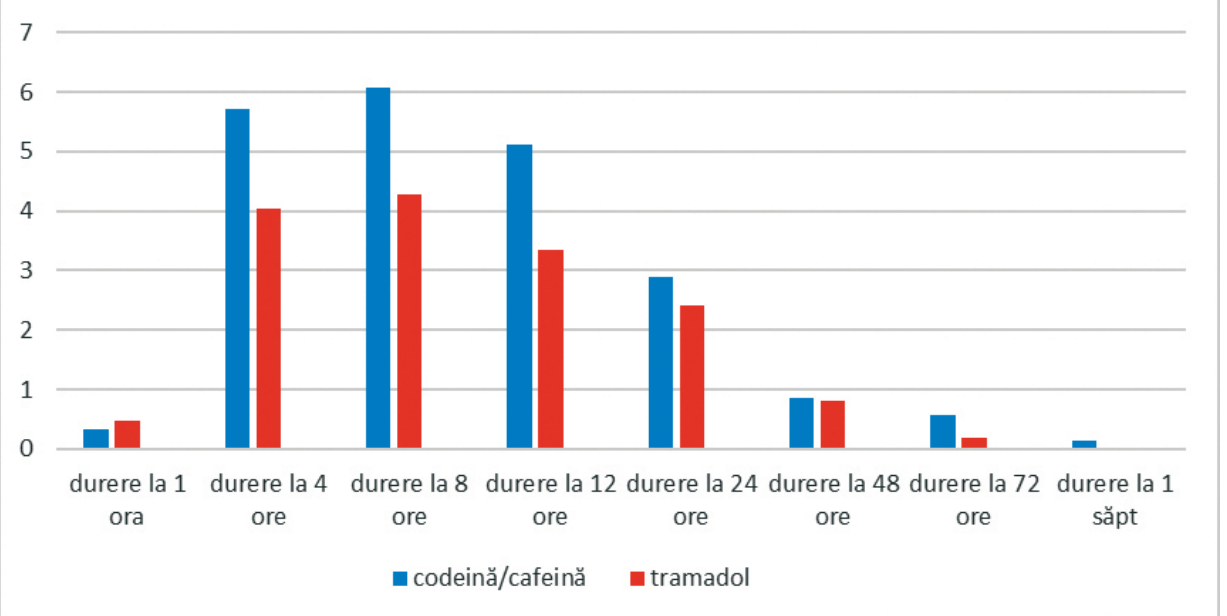

FIGURA 2. Severitatea durerii la diferite intervale de studiu pentru fiecare lot 


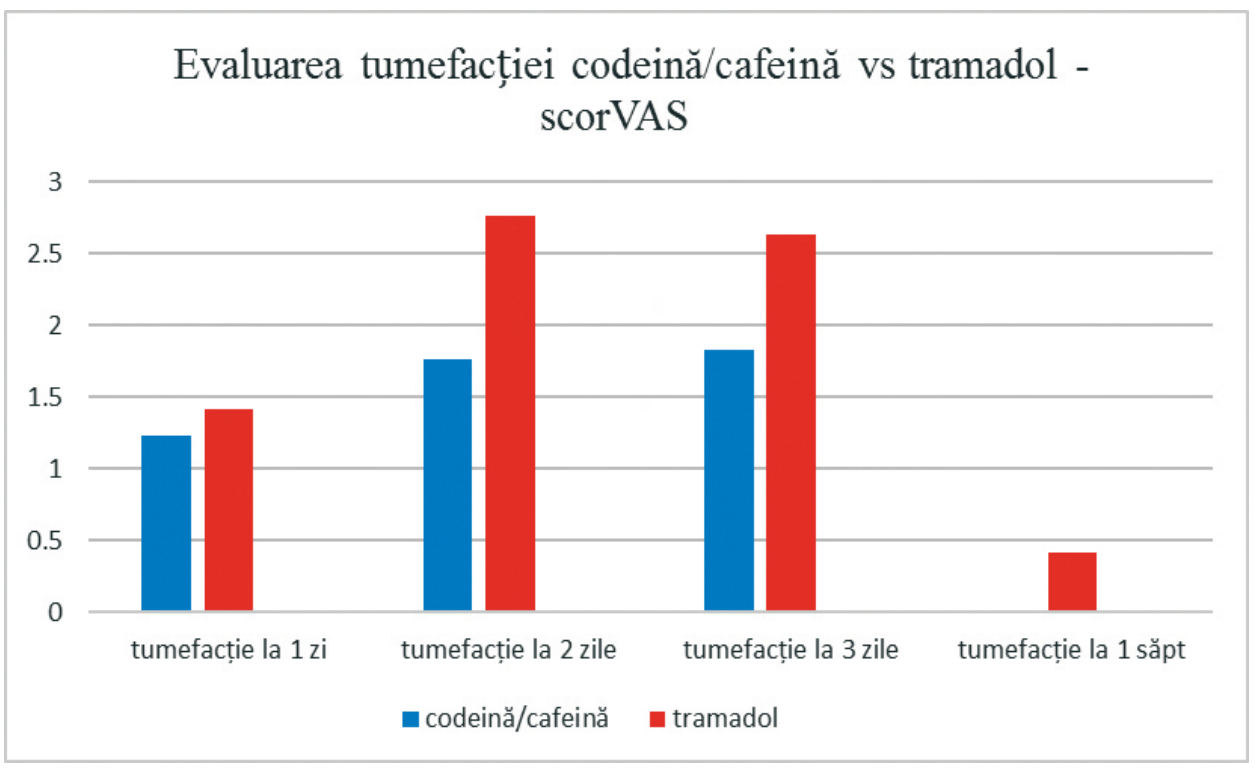

FIGURA 3. Tendința de inflamație în timpul acestui studiu, pentru fiecare lot.

după implantare. $\mathrm{Cu}$ toate acestea, din prima zi după intervenţie până la o săptămână, diferenţa nu a fost semnificativă. A fost de asemenea observat la toate intervalele de timp că severitatea tumefacţiei după intervenţia chirurgicală în lotul II a fost semnificativ mai scăzută decât cea din lotul I.

Inserarea implantului provoacă de obicei durere şi inflamaţie locală uşoară până la moderată şi rareori severe, în funcţie de timpul şi dificultatea intervenţiei chirurgicale, densitatea osoasă, reactivitatea pacientului, efectul anestezic local $(11,13,23)$. Prin urmare, este necesar să se prescrie medicamente analgezice şi antiinflamatoare adecvate postimplantar.

Studiile au arătat că utilizarea AINS pentru controlul implantului pot afecta osteointegrarea implantului $(1,6,12,14,24)$. Se pare că AINS au efecte negative asupra formării osoase postoperator prin enzima Cox-2 (12). Cu toate acestea, a fost arătat că acest efect negativ este temporar şi nu afectează integrarea osoasă finală. Noi studii privind indicarea AINS pentru controlul durerii după intervenţia chirurgicală au arătat şi rezultate contradictorii, în unele cazuri care sugerează că utilizarea pe termen lung a AINS (peste o săptămână) ar putea afecta osteointegrarea implanturilor $(1,6,12,14,24)$. Pe de altă parte, Macedo şi colab. au raportat în 2015 despre cafeină că acţionează ca antioxidant, anti-mutaţie, angiogenic şi antiinflamator (17), fiind util în procesul de osteointegrare. De asemenea, are efecte vasoconstrictoare asupra vaselor periferice.
Studiile au arătat că analgezice care conţin un opioid, cum ar fi clorhidratul de tramadol şi fosfatul de codeină, sunt eficiente în scăderea durerii medii după intervenţia chirurgicală $(10,19)$. Este de remarcat faptul ca durerea a atins un maxim în ambele loturi la intervalul de 8 ore postoperator.

Majoritatea pacienţilor au avut durere mică sau deloc la 1 oră după intervenţie, datorită unui efect local al anestezicului; totuşi, durerea a început la 4 ore postoperator în ambele grupuri, odată cu metabolizarea anestezicului, şi scade în timp până la intervalul de 1 săptămână. S-a observat că severitatea durerii în lotul I la intervalele 4,8 şi 12 ore postoperator a fost semnificativ mai mică decât cei din lotul II. $\mathrm{Cu}$ toate acestea, la alte intervale, durerea nu a fost semnificativ diferită între cele două grupuri. Chiar şi la intervalele postoperatorii de 4,8 şi 12 ore, nivelul de durere în cele două grupuri a fost înregistrat ca moderat (VAS a fost între 3 şi 7 ani). $\mathrm{Cu}$ alte cuvinte, efectele analgezice ale substanţelor pe bază de codeină/cofeină, cu o mică întârziere, erau aproape de cele ale analgezicelor pe bază de tramadol.

Tumefacţia în lotul II a fost semnificativ mai mică decât tumefacţia din lotul I în prima, a 2-a şi a 3-a zi. $\mathrm{Cu}$ toate acestea, după o săptămână, nu au existat diferenţe semnificative între cele 2 loturi. Severitatea tumefacţiei în ambele loturi s-a schimbat semnificativ în timp. Aceasta a atins un maxim în ambele loturi în a doua zi postoperator şi de la a treia zi până la 1 săptămână după intervenţia chirur- 
gicală a scăzut. Ambele grupuri au prezentat cele mai mici inflamaţii locale după o săptămână.

Severitatea tumefacţiilor din lotul II a fost mai mică decât cea înregistrată în lotul I, astfel încât s-a ajuns la concluzia că efectul antiinflamator al cofeinei a fost semnificativ mai mare decât cel al clorhidratului de tramadol, care ar putea fi atribuit mecanismului vasoconstrictor al cofeinei în vasele de sânge din zona maxilo-facială prin afectarea receptorilor A1 şi stimularea sistemului nervos simpatic. Acest proces ar creşte eliberarea de catecolamine şi ar stimula axa renină-angiotensină-aldosteron. Articole publicate susţin acest lucru, ideea naturii vasoconstrictoare a cofeinei rezultând într-o scăderea scăzută a inflamaţiei comparativ cu opioidele $(9,18)$.

Severitatea inflamaţiei după intervenţii chirurgicale orale, în special în absenţa unui proces infecţios, scade în a treia zi până în prima săptămână post- operator $(8,20,21)$. Rezultatele studiului confirmă această tendinţă în ambele grupuri.

\section{CONCLUZII}

Conform acestui studiu, analgezicele cu conţinut pe bază de tramadol sunt semnificativ mai eficiente decât cele care conţin codeină/cafeină în reducerea durerii postoperatorii. S-a concluzionat, de asemenea, că această combinaţie pe bază de codeină/cafeină/acetaminofen este semnificativ mai eficientă decât combinaţia pe bază de tramadol/acetaminofen în reducerea tumefacţiei postoperatorii, în primele 3 zile.

\section{Menţiune}

Toţi autorii au contribuţie egală în realizarea acestui articol.

\section{BIBLIOGRAFIE}

1. Alissa R, Sakka S. Oliver R. Homer K. Esposito M, Worthington HV. et al: Infiuence of ibuprofen on bone healing around dental implants: a randomised double-blind placebo-controlled clinical study. EurJ Oral Implantol 2: 185-199, 2009

2. Astorino TA, Terzi MN, Roberson DW, Burnett TR: Effect of caffeine intake on pain perception during high intensity exercise. In tJ Sport Nutr Exerc Metab 21: 27-32, 2011

3. Barasch A, Salford MM, McNeal SF. Robinson M, Grant VS, Gilbert $\mathrm{GH}$ : Pattems of postoperadve pain medication prescribing after invasive dental procedures. Spec Care Dent 31: 53-57. 2011

4. Benowilz Nl; Clinical pharmacology of caffeine. Annu Rev Med 41: 277-288, 1990

5. Bryce G, Bomfinn DI, Bassi GS: Pre- and post-operative management of dental implant placement. Part 1: management of post-operative pain. $\mathrm{Br}$ Dent] 217: IB-127, 2014

6. Cai WX, Ma L Zheng LW, Kruse-Gujer A, Stubinger S, Lang NR et al: Influence of non-stemidal anti-inflammatory dnigs (NSAIDs) on osseointegration of dental implants in rabbit calvaria. Clin Oral Implants Res 26: 478-483, 2015

7. Chaturvedi A, Chaturvedi S. Sivasankar R: Image-guided lumbar facet joint infil tration in nonradicular low back pain. Indian J Radiol Imag 19: 29-34, 2009

8. Costa FWC, Soares EC, Esses DFS, Silva PG, Bezerra TP, Scarparo $\mathrm{HC}$, et al: A split-mouth, randomized, triple blind. placebo»controlled study ro analyze the pre-emptive effect of etoricoxib $120 \mathrm{mg}$ on inflammatory events following removal of unerupted mandibular third molars. Int J Oral Maxillofac Surg 3: 1-9, 2015

9. Echeverri D, Montes FR, Cabrera M, Galan A, Prieto A: Cafleine's vascular mechanisms of action. Int J vasc Med 201083406112010

10. Forbes JA, Bates JA Edquist IA, Burchheld WH, Smith FG, Schwartz MK, et al; Evaluation of two opioid-acetaminophen combinations and placebo in postoperative oral surgery pain. Phamiacotherapy 1 : 139-146, 1994

11. Goiato MC, junior S, Ferreira j, Pellizzer EP, Moreno A, Villa LMR, et al: Systemic trans-and postoperative evaluations of patients undergoing dental implant surgery. Clinics 71. 156-162, 2016
12. Gomes Fl, Aragao MG, de Paulo Teixeira Pinto V, Gondim DV Barroso FC, Silva AA et al: Effects of nonsteroidal anti-inflammatory drugs on olsseointegration a review. J Oral Implantol 41: 219-230, 2015

13. Gonzalez-Santana H, Penarrocha-Diago M, Guarinos-Carbo, J Balguerer-Martinez J: Pain and inflammation in 41 patients following the placement of 131 dental implants. Med Oral Patol Oral Cir Bucal 10: 258-263, 2005

14. Jeffcoat MK, Reddy MS, Wang IC, Meuninghoff LA. Farme JB, Koth $\mathrm{DL}$ :The effect of sistemic flurbiprophen on bone supporting dental implant. J.Am Dent Assoc 126: 305-311, 1995, qiuz 46-7

15. Jung YS, Kim DK, Kim MK, Kim I-lj, Cha IH, Lee EW: Onset ofanalgesia and efficacy of tramadol/acetaminophen and codeine/ acetaminophen/ibuprofen in acute postoperative pain: a singlecenter, single-dose, randomized, active-controlled parallel-group study in a dental surgery pain model. Clin Ther 26: 1037-1045,2004

16. Kjaersgaard-Andersen P. Nafei A, Skov O. Madsen F Andersen HM, Kroner $\mathrm{K}$, et al: Codeine plus paracetamol versus paracetamol in longer-term treatment of chronic pain due to osteoarthritis of the hip. A randomized, double-blind, multi-center study. Pain 43: 309-318, 1990

17. Macedo RM, Brentegani LG, Lacerda SAD: Effect of coffee intake and intraperitoneal cafeine on bone repair process - a histologic and histometric stuy. Braz Dent J 26: 175-180, 2015

18. Merry AF, Gibbs RD, Edwards 1, Ting GS, Frampton C, Davies F. et al: Combined acetaminophen and ibuprofen for pain relief after oral surgery in adults: a randomized controlled trial. BrJ Anaesth 104: $\$ 0-88.2010$

19. Moore RA, Derry S, McQuay HJ. Wiffen PJ: Single dose oral analgesics for acuig postoperative pain in adults. Cochrane Database Syst Rev BCD008659, 2011

20. Pasqualini D, Cocero N, Castella A, Mela L Bracco P: Primary and secondary closure of the surgical wound after removal of impacted mandibular third molars: a comparative study. Int] Oral Maxillofac Surg 34: 52-57, 2005

21. Pouchain E. Costa Bezerra T. Soares E: Comparative efficacy of nimesulide and ketoprofen on inflammatory events in third molar 
surgery: a split-mouth, prospective, randomized double-blind study. Inter J Oral Maxillo Surg 44: 876-884, 2015

22. Sinatra RS. Jahr JS, Reynolds LW, Viscusi ER, Groudine SB, Payen-Campenois C:Efficacy and safety of single and repeted administration of $1 \mathrm{gram}$ intravenous acetaminophen injection (paracetamol) for pain management alter major orthopedic surgery. Anesthesiology 102:822-831, 2005

23. Spin-Neto R, Pones A, Wenzel A, Sakkura CE: Patient disconfort following single-tooth implant placement: a randomized controlled trial of immediate vs. conventional tooth restaoration. OHDM 13: 441-445, 2014
24. Winnett B, Tenenbaum HC, Ganss B, jokstad A: Perioperative use of non-steroiclal anti-intiammatory drugs might impair dental implant osseointegration. Clin Oral Implants Res 27: e1 -7, 2014

25. Yoon E. Babar A, Choudhary M, Kurner M, Pyrsopoulos N: Acetaminophen- induced hepatotoxicity: a comprehensive update. J Clin Trans Hepatol 4:131-142, 2016

26. Zylka MJ: Pain-relieving prospects for adenosine receptors and ectonucleotidases, Trends Mol Med 17: 188-196, 2011 